\title{
Comparison of primary and secondary metabolite compositions and antioxidant effects of specific soybean cultivars
}

\author{
Chung Eun Hwang ${ }^{1,2}$, Su Cheul Kim ${ }^{1}$, Jin Hwan Lee ${ }^{3}$, \\ Dong-Hee Lee ${ }^{4}$, Kye Man Cho ${ }^{1,5 *}$ \\ ${ }^{1}$ Department of Food Science, Gyeongnam National University of Science and Technology, Jinju 52725, Korea \\ ${ }^{2}$ Department of Research \& Development, Jinju Bioindustry Foundation, Jinju 52839, Korea \\ ${ }^{3}$ Department of Life Resources Industry, Dong-A University, Busan 49315, Korea \\ ${ }^{4}$ Industry Academy Cooperation Foundation, Andong National University, Andong 36729, Korea \\ ${ }^{5}$ Herbal Medicine Resources Research, Korea Institute of Oriental Medicine, Naju 58245, Korea
}

특이 콩 품종의 1 차 대사체와 2 차 대사체 조성 및 항산화 활성 비교

\author{
황정은 ${ }^{1,2} \cdot$ 김수철 $^{1} \cdot$ 이진환 $^{3} \cdot$ 이동희 ${ }^{4}$ 조계 만 $^{1,5 *}$ \\ ${ }^{1}$ 경남과학기술대학교 식품과학부, ${ }^{2}$ (재)진주바이오산업진흥원 연구개발실, \\ ${ }^{3}$ 동아대학교 생명자원산업학과, ${ }^{4}$ 안동대학교 산학협력단, \\ ${ }^{5}$ 한국한의학연구원 한약자원연구센터
}

\begin{abstract}
The metabolite composition and antioxidant activity of the Saedanbaek, Jinyang, and Wooram soybean cultivars were evaluated. The moisture, crude ash, protein, fat, and carbohydrate contents in these soybean cultivars varied in the range 7.9-9.8 mg/g, 4.8-4.9 mg/g, 35.9-47.5 mg/g, 14.2-16.5 mg/g, and 21.4-35.0 $\mathrm{mg} / \mathrm{g}$, respectively. The crude protein content was found to be the highest $47.5 \mathrm{mg} / \mathrm{g}$ in the Saedanbaek soybean. The contents of saturated fatty acids such as palmitic acid, arachidic acid, behenic acid, and lignoceric acid were 1391.1, 490.8, 37.5, 44.9, and $16.6 \mathrm{mg} / 100 \mathrm{~g}$, respectively, and were the highest in the Jinyang soybean. The unsaturated fatty acids (linoleic acid, oleic acid, and a-linolenic acid) were estimated to be $8258.0,2896.8$, and $906.5 \mathrm{mg} / 100 \mathrm{~g}$, respectively, in the Saedanbaek, Jinyang, and Wooram soybeans. The highest total amino acid content $(44598.54 \mathrm{mg} / 100 \mathrm{~g})$ was found in the Saedanbaek soybean, and this was almost 2 and 1.6 folds higher than those in the Jinyang (21,525.93 $\mathrm{mg} / 100 \mathrm{~g})$ and Wooram $(26,250.63 \mathrm{mg} / 100 \mathrm{~g})$ soybeans. The highest glycosides, malonylglycosides, and aglycone contents $(836.46 \mu \mathrm{g} / \mathrm{g}, 2,975.86 \mu \mathrm{g} / \mathrm{g}$, and $231.60 \mu \mathrm{g} / \mathrm{g}$, respectively) were found in the Wooram soybean.
\end{abstract}

Key words : soybean cultivar, fatty acid, amino acid, isoflavone, antioxidant activity

\section{서 론}

두과작물인 대두는 오래전부터 동아시아에서 주요 식량 자원으로 이용되어 왔고 현재에는 전 세계인의 건강기능

*Corresponding author. E-mail : kmcho@gntech.ac.kr Phone : 82-55-751-3272, Fax : 82-55-751-3279

Received 26 April 2019; Revised 17 July 2019; Accepted 25 July 2019.

Copyright (c) The Korean Society of Food Preservation. All rights reserved.
식품 원재료로 각광받고 있는 작물 중 하나이다(1). 한국에 서는 오곡에 포함되며 쌀, 기장, 보리, 조 등과 함께 재배되 고 있으며 특히 식물성 단백질 함량과 지방의 주요 공급원 으로 사용되고 있다(1). 대두는 양질의 단백질과 불포화 지방산 외 oligosaccharide, phytosterol, phytic acid, dietary fiber, saponin, trypsin inhibitor, isoflavone 등의 화합물들을 함유하고 있다(2). 좀 더 상세하게는 대두 단백질과 같은 1 차 대사체는 혈중 콜레스테롤 농도 감소와 심혈관계 질환 인 죽상동맥경화증 예방에 효과가 탁월하며 2차 대사체인 phytochemical(saponin 및 isoflavone) 화합물들은 항산화, 
항암, 항염증에 우수한 것으로 보고되어 있다(3).

대두에 천연적으로 함유되어 있는 여러 생리활성 물질 중 이소플라본은 antiestrogen 효과가 있어 식물성 estrogen 으로 불리며 건강을 중요시하는 현대인들의 식생활 개선에 아주 중요한 역할을 하고 있다(4). 대두에 함유된 이소플라 본 유도체들은 aglycones(daidzein, genistein, glycitein)와 같 은 비배당체와 포도당 결합 형태인 glucosides(daidzin, genistin, glycitin), acetyl-glucosides(daidzin, genistin, glycitin), 및 malonyl-glucosides(daidzin, genistin, glycitin)와 같은 배 당체 형태로 존재한다(5). 또한 이소플라본은 대두 품종에 따라 조금씩 차이는 있으나 보통 대두의 경우 malonyl glucosides 형태가 약 $80 \%$ 로 상당량을 차지하고 있으며 glucosides 형태가 $25 \%$ 정도 분포되어 있고 acetyl glucosides 형태는 극미량 함유되어 있으며 aglycones 형태는 약 $2 \%$ 정도 함유되어 있는 것으로 보고되었다(6). 현재 이소플라 본은 콩에서 12 종류가 발견되었고 이들 유도체 모두 생리 활성을 나타내지만 특히 비배당체 이소플라본이 우수한 활성을 나타내는 연구가 보고되었다(7).

한편, 대두는 콩 품종에 따라 각각 다른 종류의 식품제조 에 사용되어 왔으며 대표적으로 장류(된장 및 고추장), 식용 유, 두부, 유부 또는 두유 등의 가공에는 노란콩인 백태가 주로 사용되며 검정콩의 서리태 등은 조림 등에 이용되어 왔다. 또한 백태는 중립 또는 대립으로 백립중당 20-25 g 정도로 분류되며 검정콩은 28-29 g으로 극대립, 콩나물 콩 은 소립(8-12 g)으로 분류되어 있다(6). 이러한 콩은 품종과 색 차이에 따라 수용성 페놀릭스, 플라보노이드 또는 이소 플라본 함량과 항산화 활성의 차이가 있는 것으로 Cho 등 (8)은 보고하였다. 이렇듯 콩 품종과 관련된 연구 결과로는 최근 $\mathrm{Kim}$ 등(9)이 발표한 품종별 발아콩의 이소플라본 함 량 비교와 Lee 등(1)의 장류 및 두부용(대원, 신팔달 2호, 진품 2호, 태광), 콩나물용(소명, 푸른)과 밥밑용(검정 2호, 선흑) 콩의 일반성분과 기능성 성분분석 결과가 존재한다. 이외에도 국내에서 유통되는 노란콩과 검정콩의 지방함량 (10)과 콩 종류에 따른 아미노산 함량(11) 연구 등 유사 연구는 국내에서 여럿 보고되었다.

한편, 본 연구에서 사용한 새단백 콩은 기존의 단백콩보 다 단백질 함량 $(48 \%$ 이상)을 증대시킨 품종으로 국내 특이 품종 중 하나이다(12). 이 외 진양콩은 콩 특유의 비린내가 결여된 품종이며(13) 우람콩은 기계 수확 적응성이 우수하 여 장류 또는 두부 가공 적성이 뛰어난 신품종이다(14). 현재 국산콩에 관한 연구는 많이 보고되었으나 특이 품종간 의 성분 비교 분석 연구는 미흡한 것으로 조사되었다.

그러므로 본 연구에서는 각각의 특징이 있는 국내 특이 콩 품종간 1 차 대사체 함량과 이들 추출물에 따른 2 차 대사 체 함량 및 생리활성을 비교 분석함으로써 향후 두부 또는 장류 등의 콩 가공공정에 적합한 품종을 활용하기 위한 목적으로 본 연구를 수행하였다.

\section{재료 및 방법}

\section{실험재료 및 시약}

본 연구에서 사용한 콩(Glycine $\max$ Merr) 중 새단백, 진양 및 우람 품종은 2015년도에 농촌진흥청에서 재배 및 수확된 것을 제공받아 사용하였다. 각각의 콩 품종에 함유 되어 있는 이소플라본 배당체 중 glycitin, genistin, daidzin 표준품은 Indofine(Hillsborough, NJ, USA)에서 구입하였고 또 다른 배당체 형태의 malonyl glycitin, malonyl genistin, malonyl daidzin 표준품은 LC Laboratories(Woburn, MA, USA)에서 구입하였고 비배당체(daidzein, genistein, glycitein) 표준품은 Sigma-Aldrich(St, Louis, MO, USA)에서 구입하 였다. 2,4,6-azino-bis(3-ethylbenzthiazoline-6-sulphnoic acid) (ABTS), 2,2-diphenyl-1-picrydrazyl(DPPH), trifluoroacetic acid(TCA), thiobarbituric acid (TBA), p-nitrophenyl-a -D-glucopyranoside(p-NPG), p-nitrophenyl-butyrate(p-NPB), a-glucosidase, 및 pancreatic lipase 역시 Sigma-Aldrich에서 구입하여 사용하였다. 각각의 콩 품종별 추출물 제조와 항 산화 활성과 기기분석 등에 사용한 유기용매(methanol, acetonitrile, water 및 acetic acid 등)는 J.T.Baker(Philipsbug, $\mathrm{NJ}, \mathrm{USA}$ )에서 구입하여 사용하였고 이 외 기타시약은 필요 에 따라서 분석용 1 급 또는 특급시약을 구입하여 사용하였 다.

\section{분석기기}

지방산 분석은 gas chromatography(GC, Agilent 7890A, Boeblingen, Germany)를 사용하였고 아미노산 분석은 자동 아미노산 분석기(Hitachi, L-8900, Tokyo, Japan)를 사용하 여 분석하였으며 이소플라본 분석은 high performance liquid chromatography(HPLC, Agilent 1,200 system)를 사용 하여 분석하였다. 이 외 라디칼 소거활성 및 소화효소 저해 활성 측정은 분광광도계(UV-1800 240V, shimadzu, Kyoto, Japan)를 사용하여 측정하였다.

\section{영양성분 분석}

새단백, 진양, 및 우람콩 품종의 영양성분은 수분, 회분, 조단백, 조지방, 탄수화물로 구성하여 식품 및 식품첨가물 공전(15)에 따라 분석하였다. 즉, 수분과 회분 함량은 각각 상압가열건조법과 건열회화법으로 측정하였고 조지방과 조단백 함량은 각각 Soxhelt과 Micro-Kjeldahl법을 적용하 여 수행하였다. 탄수화물 함량은 상기 각 성분의 합을 100 에 서 뺀 값을 적용하였으며 $\mathrm{mg} / \mathrm{g}$ 으로 표시하여 나타내었다.

\section{지방산 및 아미노산 분석}

새단백, 진양, 및 우람콩 품종의 지방산 함량은 Lee 등 (3)의 논문에 준하여 정량분석을 하였다. 각각의 원료콩 분말 $1 \mathrm{~g}$ 에 메탄올성 $0.5 \mathrm{~N}$ 수산화나트륨 용액 $3 \mathrm{~mL}$ 를 
가하여 $100^{\circ} \mathrm{C}$ 에서 10 분간 가열하여 지방산과 글리세롤을 가수분해 하였다. 가수분해에 이어 삼불화붕소 $\left(\mathrm{BF}_{3}\right) 2 \mathrm{~mL}$ 를 첨가하여 30 분간 다시 가열하여 지방산 메틸에스테르화 를 진행하였다. 반응 종료 후에는 이소옥탄 $1 \mathrm{~mL}$ 를 첨가하 고 격렬히 흔든 후 방치시켜 이소옥탄 층에 녹아든 유지층 만을 회수하여 무수아황산나트륨과 함께 탈수한 뒤 0.45 um-membrane filter(Dismic-25CS, Toyoroshikaisha, Ltd., Tokyo, Japan)로 여과하여 분석시료를 제조하였다. $\mathrm{GC}$ 는 질소 및 수소가스와 SP-2560 모세관 컬럼 $(100 \mathrm{~m} \times 0.25 \mathrm{~mm}$, $0.25 \mu \mathrm{m})$ 및 형광검출기가 장착된 것을 사용하였다. 상세 분석조건으로는 oven의 초기온도는 $180^{\circ} \mathrm{C}$ 로 설정하여 분 당 $4^{\circ} \mathrm{C}$ 조건으로 점차 승온시켜 최종 $230^{\circ} \mathrm{C}$ 로 상승시켰으며 각각의 시료량은 $10 \mu \mathrm{L}$ 를 주입하여 35 분간 형광검출기상에 서 지방산 함량을 검출하였다.

아미노산 분석은 Hwang 등(12)의 방법을 약간 변형하여 실시하였다. 시료 $100 \mathrm{mg}$ 을 시험관에 정확히 칭량하고 여 기에 $6 \mathrm{~N} \mathrm{HCl}$ 을 $3 \mathrm{~mL}$ 가하여 $110^{\circ} \mathrm{C}$ 에서 24 시간 동안 가수분 해를 실시하였다. 가수분해 액은 glass filter로 여과하고 얻 은 여액을 $60^{\circ} \mathrm{C}$ 에서 감압 농축하여 $\mathrm{HCl}$ 과 물을 완전 건조하 였다. 건조된 시료는 soduim citrate buffer(pH 2.2) $2 \mathrm{~mL}$ 를 첨가하여 용해 후 $0.45 \mu \mathrm{m}$ membrane filter(Dismic-25CS, Toyoroshikaisha Ltd, Tokyo, Japan)로 여과한 여액을 아미노 산 자동분석기(Hitachi L-8900, Tokyo, Japan)를 사용하여 분석하였으며 $\mathrm{mg} / 100 \mathrm{~g}$ 으로 나타내었다.

\section{추출물 제조}

각각의 품종별 콩 분말 $10 \mathrm{~g}$ 에 HPLC 등급의 메탄올 100 $\mathrm{mL}$ 를 가하고 $25^{\circ} \mathrm{C}$ 환경에서 $12-16$ 시간 정도 교반시키고 원심분리 하여 상층만을 회수하고 이를 $0.45 \mu \mathrm{m}$ membrane filter로 여과하여 추출물을 제조하였다. 이 추출물은 이소 플라본 분석과 항산화 활성 및 소화효소 저해활성 측정 시료로 사용하였다.

\section{이소플라본 분석}

이소플라본 분석은 Lee 등(16)이 최근 보고한 연구방법 에 준하여 HPLC로 분석하였다. 분석에 사용된 컬럼은 Lichrophore $100 \mathrm{RP} \mathrm{C}_{18}$ 이며 이동상 용매는 $0.2 \%$ 초산 함유 HPLC 등급의 water와 $0.2 \%$ 초산 함유 HPLC 등급의 아세토 나이트릴을 각각 $\mathrm{A}$ 와 $\mathrm{B}$ 용매로 설정하여 분석하였다. 각 이동상 용매의 농도구배조건은 $\mathrm{A}$ 용매 기준으로 $100 \%(0$ 분), $90 \%$ (15분), $80 \%$ (25분), $75 \%$ (35분), $65 \%$ (45분) 및 $65 \%$ (50분)로 설정하였다. 시료 주입량은 $20 \mu \mathrm{L}$ 로 설정하였 고 이동상 속도는 $30^{\circ} \mathrm{C}$ 에서 분당 $1 \mathrm{~mL}$ 의 유속으로 diode array detector(DAD)를 통과하여 $254 \mathrm{~nm}$ 에서 검출되도록 설정하였다.

\section{항산화능 측정}

$\mathrm{DPPH}$ 라디칼 소거활성은 Hwang 등(17)의 결과를 바탕 으로 상기 기술된바와 같이 제조된 각각의 추출물(0.1 $\mathrm{mg} / \mathrm{mL}) 0.2 \mathrm{~mL}$ 를 시험관에 취하고 메탄올에 녹인 $\mathrm{DPPH}$ 용액 $(0.4 \mathrm{mM})$ 을 가하여 암실에서 30 분간 반응시켜 $525 \mathrm{~nm}$ 에서 흡광도를 측정하였다.

ABTS 라디칼 소거활성은 측정 전날 ABTS 용액 $(7.4 \mathrm{mM})$ 과 $2.6 \mathrm{mM}$ 의 potassium persulphate를 1:1로 혼합하여 암실 에서 방치하여 $\mathrm{ABTS}$ 양이온을 형성시켰다. 양이온이 형성 된 ABTS 용액과 HPLC 등급의 메탄올을 희석시켜 $732 \mathrm{~nm}$ 에서 흡광도 값이 $0.7 \pm 0.1$ 로 조제된 $\mathrm{ABTS}$ 용액 $0.9 \mathrm{~mL}$ 에 각각의 추출물 $0.1 \mathrm{~mL}$ 를 가하고 정확히 3 분후에 $732 \mathrm{~nm}$ 에 서 흡광도 값을 측정하였다(18).

Hydroxyl 라디칼 소거활성은 시험관에 $\mathrm{FeSO}_{4}$-EDTA 용 액 $(10 \mathrm{mM}) 0.2 \mathrm{~mL}, 2$-deoxylribose $(10 \mathrm{mM}) 0.2 \mathrm{~mL}$, 각각의 추출물 $1.2 \mathrm{~mL}$ 와 $\mathrm{H}_{2} \mathrm{O}_{2}(10 \mathrm{mM}) 0.4 \mathrm{~mL}$ 를 순차적으로 첨가 하고 $37^{\circ} \mathrm{C}$ 에서 4 시간 반응시켰다. 반응 후 여기에 HPLC water에 용해된 $\mathrm{TBA}(1 \%)$ 와 $\mathrm{TCA}(2.8 \%)$ 를 $1 \mathrm{~mL}$ 씩 가한 후 $100^{\circ} \mathrm{C}$ 에서 20 분간 발색시키고 냉각 후 $525 \mathrm{~nm}$ 에서 흡광도 변화를 측정하였다(19). 모든 항산화 활성은 시료 첨가구와 무첨가구 사이의 흡광도 차이를 \%로 나타내었으며 아래와 같은 식에 의해 산출하였다.

항산화 활성 $(\%)=(1-$ 시료첨가구 흡광도 값 / 무첨가구 흡광도 값) $) \times 100$

\section{효소 저해능 측정}

a-Glucosidase 저해활성은 $200 \mathrm{mM}$ sodium phosphate buffer(pH 7.0)를 제조하고 여기에 $\mathrm{p}-\mathrm{NPG}$ 를 $5 \mathrm{mM}$ 농도로 녹인 후 각 시료 추출물과 기질용액을 $1.0 \mathrm{~mL}$ 씩 첨가하여 수옥조 $\left(37^{\circ} \mathrm{C}\right)$ 에서 15 분 예비반응을 시켰다. 이 반응물에 효소용액 $(30 \mathrm{U} / \mathrm{mL})$ 을 $1.0 \mathrm{~mL}$ 추가하고 다시 $37^{\circ} \mathrm{C}$ 에서 15 분 간 본 반응을 진행하였다. 반응 후에는 $\mathrm{Na}_{2} \mathrm{CO}_{3}(100 \mathrm{mM})$ 용액을 $0.75 \mathrm{~mL}$ 만큼 첨가하여 반응을 종료 시킨 것을 일정 량 채취하여 $420 \mathrm{~nm}$ 에서 흡광도 값을 측정하였다(20).

Pancreatic lipase 저해활성 역시 a-glucosidase 저해활성 과 유사한 방법으로 측정하였다. 각 추출물과 lipase 효소용 액 $(30 \mathrm{U} / \mathrm{mL})$ 을 eppendorf tube에 $50 \mathrm{uL}$ 씩 첨가하고 여기에 sodium phosphate buffer $(200 \mathrm{mM}, \mathrm{pH} 7.0) 50 \mathrm{uL}$ 를 추가하여 수옥상에서 예비반응을 10 분간 진행하였다. 예비반응 후 sodium phosphate buffer에 용해된 p-NPB $(5 \mathrm{mM})$ 를 $100 \mathrm{uL}$ 첨가 후 동일하게 $37^{\circ} \mathrm{C}$ 에서 10 분간 본 반응시키고 반응 종료를 위해 $\mathrm{Na}_{2} \mathrm{CO}_{3}(100 \mathrm{mM}) 0.75 \mathrm{~mL}$ 를 첨가하고 420 $\mathrm{nm}$ 에서 흡광도를 측정하였다. 이때 모든 효소 저해활성 역시 시료 첨가구와 무첨가구 사이의 흡광도 차이를 \%로 나타내었으며 아래와 같은 식에 의해 산출하였다(20). 
효소 저해 활성 $(\%)=(1-$ (시료첨가구 흡광도 값 / 무첨가구 흡광도 값) $) \times 100$

\section{통계처리}

각 실험은 3 회 반복 수행하였고 본 결과는 SPSS 12.0 package 시스템으로 분산 분석을 실시하였으며 평균 \pm 표준 편차로 나타내었다. 각각의 분석 결과에 대한 유의성 검정 은 분산 분석 후 $\mathrm{p}<0.05$ 수준에서 Duncant's multiple range test를 실시하였다.

\section{결과 및 고찰}

\section{특이 콩 품종별 영양성분 비교}

새단백, 진양, 및 우람콩 품종의 영양성분을 분석한 결과 는 Table 1과 같았다. 수분 함량은 우람콩이 $12.7 \mathrm{~g} / 100 \mathrm{~g}$ 으 로 가장 많았고 새단백콩은 $9.8 \mathrm{~g} / 100 \mathrm{~g}$, 진양콩은 $7.9 \mathrm{~g} / 100$ $\mathrm{g}$ 을 나타내었다. 조회분은 $4.8-4.9 \mathrm{~g} / 100 \mathrm{~g}$ 으로 유사하였고 조단백질 함량은 새단백콩이 $47.5 \mathrm{~g} / 100 \mathrm{~g}$ 으로 가장 많았으 며 진양콩 $(38.1 \mathrm{~g} / 100 \mathrm{~g})$ 과 우람콩 $(35.9 \mathrm{~g} / 100 \mathrm{~g})$ 의 조단백질 함량은 유사하였다. 조지방 함량은 새단백 $(16.5 \mathrm{~g} / 100 \mathrm{~g})$, 진양 $(14.2 \mathrm{~g} / 100 \mathrm{~g})$, 및 우람콩 $(12.0 \mathrm{~g} / 100 \mathrm{~g})$ 순으로 많았으 며 탄수화물은 진양콩이 $35.0 \mathrm{~g} / 100 \mathrm{~g}$ 으로 가장 많았고 새단 백콩이 $21.4 \mathrm{~g} / 100 \mathrm{~g}$ 으로 가장 낮았다.

Table 1. Proximate analysis of variations soybean cultivars

\begin{tabular}{cccc}
\hline \multirow{2}{*}{ Contents (g/100 g) } & \multicolumn{3}{c}{ Soybean cultivars } \\
\cline { 2 - 4 } & Saedanbaek & Jinyang & Wooram \\
\hline Moisture & $9.8 \pm 0.49^{\mathrm{d} 1)}$ & $7.9 \pm 0.40^{\mathrm{d}}$ & $8.7 \pm 0.44^{\mathrm{c}}$ \\
Crude ash & $4.9 \pm 0.25^{\mathrm{e}}$ & $4.8 \pm 0.24^{\mathrm{e}}$ & $4.8 \pm 0.24^{\mathrm{d}}$ \\
Crude protein & $47.5 \pm 2.38^{\mathrm{a}}$ & $38.1 \pm 1.91^{\mathrm{a}}$ & $35.9 \pm 1.80^{\mathrm{a}}$ \\
Crude fat & $16.5 \pm 0.83^{\mathrm{c}}$ & $14.2 \pm 0.71^{\mathrm{c}}$ & $16.0 \pm 0.80^{\mathrm{b}}$ \\
Carbohydrate & $21.4 \pm 1.07^{\mathrm{b}}$ & $35.0 \pm 1.75^{\mathrm{b}}$ & $34.6 \pm 1.73^{\mathrm{a}}$ \\
\hline
\end{tabular}

${ }^{1)}$ All values are presented as the mean \pm SD of triplicate determination. Means with different lowercase letters $(\mathrm{a}-\mathrm{e})$ indicate significant $(\mathrm{p}<0.05)$ differences of samples by Duncan's multiple range test.

Kang(21)의 연구에서는 대원콩의 조단백질 함량은 $39.37 \%$ 로 보고하였고 이는 본 연구에서 사용한 진양콩 (38.1\%)과 우람콩(35.9\%)의 조단백질 함량과 유사하였다. 또한 Lee 등(1)은 장류콩 중 대원콩, 신팔달 2 호콩, 진품 2 호콩, 태왕콩의 회분 함량은 각각 $5.29,5.41,5.45$, 및 $4.89 \%$ 로 보고하였고 이들 중 태왕콩의 회분 함량은 본 연구에서 사용된 3종류의 콩과 유사한 함량을 나타내었다. 그러나 조지방과 탄수화물의 함량은 본 연구와 큰 차이를 나타내었 으며 이러한 결과는 품종에 따른 차이가 가장 클 것으로
판단되었다. Jung 등(22)의 중북부지역에서 재배한 콩나물 콩의 일반성분 분석 결과에서는 수분 함량은 $5.45-6.49 \%$ 수준으로 본 연구에서 사용한 장류콩에 비해 수분 함량은 약간 낮은 경향을 나타내었다. 그러나 조회분과 조지방 함 량은 각각 5.19-6.24\% 및 15.62-19.06\%로 새단백, 진양, 그 리고 우람콩과 유사한 함량을 보였고 조단백질 함량 역시 $33.32-40.53 \%$ 로 나타나 본 연구에서 사용한 세 품종의 콩과 유사한 수치를 나타내었다. 한편 Lee 등(23)은 본 연구에서 사용된 품종과 동일한 새단백콩 품종의 영양성분 분석 결 과, 수분, 조회분, 조지방, 조단백, 및 탄수화물 함량이 각각 $6.93,6.07,14.19,40.97$, 및 $31.81 \%$ 로 보고하였고 조지방 및 조단백 함량은 본 연구와도 유사하였으나 수분, 조회분, 탄수화물 함량은 본 연구 결과와는 조금 차이가 있는 것으 로 나타났다. 결과적으로 같은 품종일지라도 각 성분들의 함량은 차이가 있는 것으로 나타났고 이는 품종, 생산년도, 재배시기 및 환경 등에 의한 차이일 것이며 특히 Lee 등(23) 의 연구에서 사용된 새단백콩 품종은 생산시기가 2017년도 이고 본 연구에서 사용된 새단백콩 품종은 2015년이므로 생산과 시험포장 년도에 따른 차이가 가장 큰 요인인 것으 로 생각된다.

\section{특이 콩 품종별 지방산 비교}

콩 품종에 따른 지방산을 분석한 결과는 Table 2 와 같았 다. 포화 지방산 중 palmitic acid는 진양콩이 $1,392.1 \mathrm{mg} / 100$ $\mathrm{g}$ 으로 가장 많았으며 우람콩은 $1,147.9 \mathrm{mg} / 100 \mathrm{~g}$ 으로 두 번째로 많았으며 새단백콩은 $890.9 \mathrm{mg} / 100 \mathrm{~g}$ 으로 가장 낮은 함량을 나타내었다. Stearic acid 역시 진양콩이 490.8 $\mathrm{mg} / 100 \mathrm{~g}$ 으로 가장 많았고 포화 지방산 총 함량도 $1,981.9$ $\mathrm{mg} / \mathrm{g}$ 으로 진양콩이 가장 많이 함유하고 있었다. 한편 새단 백콩은 포화지방산(arachidic acid 및 lignoceric acid)과 불포 화지방산(palmitoleic acid, $\gamma$-linoleic acid, eicosenic acid, eicosadienoic acid, arachidonic acid, erucic acid 및 nervonic acid)이 진양콩과 우람콩에 비해 대부분 검출되지 않았으나 linoleic acid 함량은 $8,258.0 \mathrm{mg} / 100 \mathrm{~g}$ 으로 월등히 높은 것으 로 나타났다. 진양콩의 linoleic acid 함량은 $4,722.5 \mathrm{mg} / 100$ $\mathrm{g}$ 이었고 우람콩은 $6,665.5 \mathrm{mg} / 100 \mathrm{~g}$ 을 함유하고 있었다. 새단백콩의 linoleic acid 함량은 진양콩에 비해서 1.75 배나 높았고 우람콩에 비해서는 1.24 배 높은 함량을 나타내었다. 지방산 총 함량은 우람콩이 $11,978.0 \mathrm{mg} / 100 \mathrm{~g}$ 으로 가장 많았고 이어서 새단백콩이 $11,658.0 \mathrm{mg} / 100 \mathrm{~g}$, 진양콩이 $10,202.0 \mathrm{mg} / 100 \mathrm{~g}$ 을 나타내었다.

콩에 함유된 지방산은 유전과 토양, 재배온도 및 환경 등에 영향을 받는 것으로 보고되었다(24). 특히 재배환경은 여러 콩 품종의 유전자 발현에 지대한 영향을 미칠 뿐만 아니라 지방 합성경로에 따라 지방산과 영양성분 조성에 큰 차이가 있는 것으로 보고되었다(24). Kim 등(10)은 117 종의 황색콩과 검정콩의 지방산 함량 조사 결과 황색콩의 
Table 2. Comparison of fatty acid contents in specific soybean cultivar

\begin{tabular}{|c|c|c|c|}
\hline \multirow{2}{*}{ Contents $(\mathrm{mg} / 100 \mathrm{~g})$} & \multicolumn{3}{|c|}{ Soybean cultivars } \\
\hline & Saedanbaek & Jinyang & Wooram \\
\hline \multicolumn{4}{|c|}{ Saturated fatty acids } \\
\hline Palmitic acid (C16:0) & $890.9 \pm 44.55^{\mathrm{el})}$ & $1,392.1 \pm 69.61^{\mathrm{f}}$ & $1,147.9 \pm 57.40^{e}$ \\
\hline Stearic acid $(\mathrm{C} 18: 0)$ & $290.4 \pm 14.52^{\mathrm{f}}$ & $490.8 \pm 24.54^{\mathrm{h}}$ & $424.2 \pm 21.21^{\mathrm{f}}$ \\
\hline Arachidic acid (C20:0) & $\mathrm{ND}^{2)}$ & $37.5 \pm 1.88^{\mathrm{i}}$ & $28.2 \pm 1.41^{\mathrm{g}}$ \\
\hline Behenic aicd (C22:0) & $4.7 \pm 0.24^{\mathrm{h}}$ & $44.9 \pm 2.25^{\mathrm{i}}$ & $37.3 \pm 1.87^{\mathrm{g}}$ \\
\hline Lignoceric acid (C24:0) & $\mathrm{ND}$ & $16.6 \pm 0.83^{j}$ & $12.3 \pm 0.62^{\mathrm{h}}$ \\
\hline Total & $1,186 \pm 59.30^{\mathrm{d}}$ & $1,981.9 \pm 99.10^{\mathrm{e}}$ & $1,649.9 \pm 82.50^{\mathrm{d}}$ \\
\hline \multicolumn{4}{|c|}{ Unsaturated fatty acids } \\
\hline Palmitoleic acid (C16:1) & $\mathrm{ND}$ & $8.3 \pm 0.42^{\mathrm{k}}$ & $6.6 \pm 0.33^{i}$ \\
\hline Oleic acid $(\mathrm{C} 18: \ln 9 \mathrm{c})$ & $2,175.8 \pm 108.79^{c}$ & $2,896.8 \pm 144.84^{d}$ & $2,717.0 \pm 135.85^{\mathrm{c}}$ \\
\hline Linoleic acid (C18:2n6c) & $8,258.0 \pm 412.90^{\mathrm{b}}$ & $4,722.5 \pm 236.13^{\mathrm{c}}$ & $6,665.5 \pm 333.28^{\mathrm{b}}$ \\
\hline ४-Linolenic acid (C18:3n6) & $\mathrm{ND}$ & ND & $1.8 \pm 0.09^{\mathrm{i}}$ \\
\hline a-Linolenic acid (C18:3n3) & $38.3 \pm 1.92 \mathrm{~g}$ & $537.9 \pm 26.90^{\mathrm{g}}$ & $906.5 \pm 45.33^{\mathrm{e}}$ \\
\hline Eicosenic acid (C20:1) & ND & $16.5 \pm 0.83^{j}$ & $14.2 \pm 0.71^{\mathrm{h}}$ \\
\hline Eicosadienoic acid (C20:2) & $\mathrm{ND}$ & $18.8 \pm 0.94^{j}$ & $4.8 \pm 0.24^{\mathrm{i}}$ \\
\hline Arachidonic acid (C20:4n6) & $\mathrm{ND}$ & $5.6 \pm 0.28^{k}$ & $3.4 \pm 0.17^{\mathrm{i}}$ \\
\hline Erucic acid (C22:1n9) & $\mathrm{ND}$ & $9.2 \pm 0.46^{\mathrm{k}}$ & $5.1 \pm 0.26^{i}$ \\
\hline Nervonic acid (C24:1) & $\mathrm{ND}$ & $4.8 \pm 0.24^{\mathrm{k}}$ & $2.7 \pm 0.14^{\mathrm{i}}$ \\
\hline Total & $10,472 \cdot 1 \pm 523.61^{\mathrm{a}}$ & $8,220.4 \pm 411.02^{b}$ & $10,327.6 \pm 516.38^{\mathrm{a}}$ \\
\hline Total fatty acids & $11,658.0 \pm 582.90^{\mathrm{a}}$ & $10,202.0 \pm 510.10^{\mathrm{a}}$ & $11,978.0 \pm 598.90^{\mathrm{a}}$ \\
\hline
\end{tabular}

\footnotetext{
${ }^{1)}$ All values are presented as the mean \pm SD of triplicate determination. Means with different lowercase letters $(\mathrm{a}-\mathrm{k})$ indicate significant $(\mathrm{p}<0.05)$ differences of samples by Duncan's multiple range test.

${ }^{2} \mathrm{ND}$, not detected.
}

경우 주요 지방산은 linoleic $\operatorname{acid}(\mathrm{C} 18: 2)>$ oleic $\operatorname{acid}(\mathrm{C} 18: 1)$ $>$ palmitic $\operatorname{acid}(\mathrm{C} 16: 0)>$ linoenic $\operatorname{acid}(\mathrm{C} 18: 3)>$ stearic $\operatorname{acid}(\mathrm{C} 18: 0)$ 순으로 보고하였고 이는 본 연구 결과와 일치하 였다. 또한 $\mathrm{Kim}$ 등(10)은 불포화 지방산 중 linoleic $\operatorname{acid}(\mathrm{C} 18: 2)$ 및 oleic $\operatorname{acid}(\mathrm{C} 18: 1)$ 가 각각 53.75 및 22.08\%를 차지함을 보고하였고 이 역시 본 연구 결과와 정확히 일치 하였다.

\section{특이 콩 품종별 아미노산 비교}

특이 콩 품종에 따른 아미노산 함량을 분석한 결과는 Table 3에 나타낸 바와 같다. 조단백질 함량이 가장 많았던 새단백콩은 아미노산 함량 역시 가장 많은 것으로 나타났 다. 새단백콩의 주요 아미노산은 감칠맛의 주성분인 glutamic acid로 $11,331.62 \mathrm{mg} / 100 \mathrm{~g}$ 이 검출되었고 진양콩은 $5,713.54 \mathrm{mg} / 100 \mathrm{~g}$, 우람콩은 $5,533.13 \mathrm{mg} / 100 \mathrm{~g}$ 이 검출되었 다. Aspartic acid 역시 비교적 많은 양이 확인되었고 각각 $7,013.14 \mathrm{mg} / 100 \mathrm{~g}$ (새단백콩), $3,149.74 \mathrm{mg} / 100 \mathrm{~g}$ (진양콩), 및 $3144.31 \mathrm{mg} / 100 \mathrm{~g}$ (우람콩)이 검출되었다. Aspartic acid 다음으로는 arginine 함량이 많았으며 새단백콩이 5492.28 $\mathrm{mg} / 100 \mathrm{~g}$ 으로 가장 많은 양을 함유하고 있었고 진양콩에서
는 $2,196.52 \mathrm{mg} / 100 \mathrm{~g}$, 우람콩에서는 $2,099.06 \mathrm{mg} / 100 \mathrm{~g}$ 이 검출됨에 따라 단백질 함량에 비례적인 결과를 보였다. 이 에 따라 비필수 아미노산 총 합은 새단백콩이 $23,482.36$ $\mathrm{mg} / 100 \mathrm{~g}$ 으로 가장 많았다. 필수 아미노산 중에서는 leucine 이 가장 많은 양이 검출되었으며 새단백콩에서는 $4,610.58$ $\mathrm{mg} / 100 \mathrm{~g}$, 진양콩에서는 $2,234.48 \mathrm{mg} / 100 \mathrm{~g}$, 우람콩에서는 $2,278.03 \mathrm{mg} / 100 \mathrm{~g}$ 이 검출되었다. Leucine 다음으로는 lysine 함량이 많은 것으로 확인되었으며 세 품종간 가장 낮은 함량을 보인 아미노산은 methionine으로 확인되었다. 한편 아미노산 총 함량 역시 새단백콩이 $44,598.54 \mathrm{mg}$ 으로 가장 많은 양이 검출되었고 우람콩은 $26,250.63 \mathrm{mg}$, 진양콩 은 21,525.93 mg이었다(Table 3).

식품에서 사용되는 아미노산은 보통 20가지 내외이며 그 중 체내에서 합성되지 않거나 필요량을 충족시킬 수 있을 정도의 양이 합성되지 않기에 필수 아미노산은 반드시 식품을 통해 섭취해야한다고 권장되고 있다(11). Im 등(11) 의 콩 종류와 조리방법에 따른 아미노산 함량 변화 연구 결과에서는 백태의 아미노산 성분으로는 isoleucine, leucine, phenylalanine과 같은 필수아미노산 9종류와 aspartic acid, cystine, tyrosin과 같은 비필수 아미노산 9종류 
Table 3. Comparison of amino acid contents in specific soybean cultivar

\begin{tabular}{|c|c|c|c|}
\hline \multirow{2}{*}{ Contents $(\mathrm{mg} / 100 \mathrm{~g})$} & \multicolumn{3}{|c|}{ Soybean cultivars } \\
\hline & Saedanbaek & Jinyang & Wooram \\
\hline \multicolumn{4}{|c|}{ Non-essential amino acids } \\
\hline Aspartic acid & $7,013.14 \pm 350.66^{\mathrm{el})}$ & $3,149.74 \pm 157.49^{d}$ & $3,144.31 \pm 157.22^{\mathrm{e}}$ \\
\hline Serine & $2,970.50 \pm 148.53^{j}$ & $1,394.62 \pm 69.73^{g}$ & $1,406.94 \pm 70.35^{\mathrm{h}}$ \\
\hline Glutamic acid & $11,331.62 \pm 566.58^{d}$ & $5,713.54 \pm 285.68^{\mathrm{c}}$ & $5,533.13 \pm 276.66^{\mathrm{d}}$ \\
\hline Glycine & $2,493.42 \pm 124.67^{\mathrm{j}}$ & $1,202.80 \pm 60.14^{\mathrm{h}}$ & $1,196.06 \pm 59.80^{\circ}$ \\
\hline Alanine & $2,540.08 \pm 127.00^{j}$ & $1,209.82 \pm 60.49^{\mathrm{h}}$ & $1,219.13 \pm 60.96^{i}$ \\
\hline Cystine & $747.42 \pm 37.37^{\mathrm{m}}$ & $358.34 \pm 17.92^{\mathrm{k}}$ & $413.04 \pm 20.65^{\mathrm{i}}$ \\
\hline Tyrosine & $1,850.10 \pm 92.51^{\mathrm{k}}$ & $843.94 \pm 42.20^{i}$ & $902.68 \pm 45.13^{\mathrm{k}}$ \\
\hline Arginine & $5,492.28 \pm 274.61^{\mathrm{f}}$ & $2,196.52 \pm 109.83^{\mathrm{e}}$ & $2,099.06 \pm 104.95^{\mathrm{f}}$ \\
\hline Totals & $23,482.36 \pm 1,174.12^{b}$ & $11,275.38 \pm 563.77^{\mathrm{b}}$ & $15,914.34 \pm 795.72^{\mathrm{b}}$ \\
\hline \multicolumn{4}{|c|}{ Essential amino acids } \\
\hline Threonine & $2,230.44 \pm 111.52^{\mathrm{j}}$ & $1,112.31 \pm 55.62^{\mathrm{h}}$ & $1,129.39 \pm 56.47^{j}$ \\
\hline Valine & $2,586.54 \pm 129.33^{j}$ & $1,260.67 \pm 63.03^{\mathrm{h}}$ & $1,235.79 \pm 61.79^{\mathrm{i}}$ \\
\hline Methionine & $550.34 \pm 27.52^{\mathrm{n}}$ & $314.26 \pm 15.71^{\mathrm{k}}$ & $292.26 \pm 14.61^{\mathrm{m}}$ \\
\hline Isoleucine & $2,669.84 \pm 133.49^{j}$ & $1,281.89 \pm 64.09^{\mathrm{h}}$ & $1,297.00 \pm 64.85^{\mathrm{i}}$ \\
\hline Leucine & $4,610.58 \pm 230.53^{g}$ & $2,234.48 \pm 111.72^{\mathrm{e}}$ & $2,278.03 \pm 113.90^{f}$ \\
\hline Phenylalanine & $3,138.04 \pm 156.90^{\mathrm{i}}$ & $1,491.66 \pm 74.58^{\mathrm{g}}$ & $1,492.42 \pm 74.62^{\mathrm{h}}$ \\
\hline Lysine & $3,665.78 \pm 183.29^{\mathrm{h}}$ & $1,754.27 \pm 87.71^{\mathrm{f}}$ & $1,798.65 \pm 89.93^{g}$ \\
\hline Histidine & $1,664.62 \pm 83.23^{\mathrm{k}}$ & $801.02 \pm 40.05^{j}$ & $812.75 \pm 40.64^{\mathrm{k}}$ \\
\hline Total & $21,116.18 \pm 1,055.81^{\mathrm{c}}$ & $10,250.55 \pm 512.53^{\mathrm{b}}$ & $10,336.29 \pm 516.81^{c}$ \\
\hline Total amino acids & $44,598.54 \pm 2,229.93^{\mathrm{a}}$ & $21,525.93 \pm 1,076.30^{\mathrm{a}}$ & $26,250.63 \pm 1,312.53^{\mathrm{a}}$ \\
\hline Ammonia & $930.30 \pm 46.521$ & $403.71 \pm 20.19^{\mathrm{k}}$ & $383.68 \pm 19.181$ \\
\hline
\end{tabular}

${ }^{1)}$ All values are presented as the mean \pm SD of triplicate determination. Means with different lowercase letters $(\mathrm{a}-\mathrm{n})$ indicate significant $(\mathrm{p}<0.05)$ differences of samples by Duncan's multiple range test.

로 보고하였고 이 결과는 본 연구 결과와도 유사한 경향을 나타내었다. $\operatorname{Kim}$ 과 $\operatorname{Kim}(25), \operatorname{Kim}$ 등(26)은 청태, 서리태, 수박태, 흑태, 서목태에 함유된 아미노산은 17종류로 보고 하였고 이 결과 역시 본 연구 결과와도 유사한 경향을 나타 내었다. 특히 Im 등(11)은 생콩에 함유된 아미노산 중 주요 성분은 glutamic acid(67.3-73.4 mg/g)로 보고하였고 그 다음 으로 aspartic acid, arginine, leucine 순으로 높은 함량을 나타 내었고 이는 본 연구 결과와 정확히 일치하였다. 이는 콩 품종에 따라 조금씩의 차이는 있을 수 있으나 일반적인 콩 단백질의 아미노산은 glutamic acid 및 aspartic acid와 같은 산성 아미노산의 함량이 가장 높으며 methionine 및 cysteine과 같은 함황 아미노산의 함량이 낮은 것이 특징이 라고 보고한 $\mathrm{Kim}$ 과 $\mathrm{Kim}(25), \mathrm{Kim}$ 등(26)의 결과와 정확히 일치하였다.

\section{특이 콩 품종별 이소플라본 유도체 비교}

9종류의 이소플라본 유도체 함량 변화에 대한 결과는 Fig. 1과 Table 4에 나타내었다. Fig. 1에 나타낸 바와 같이 배당체(peak 1; daidzin, peak 2; glycitin, peak 3; genistin, peak 4; malonyl daidzin, peak 5; malonyl glycitin, peak 6; malonyl genistin)와 비배당체(peak 7; daidzein, peak 8; glycitein, peak 9; genistein) 유도체 9종류가 검출되었다. 새단백콩의 daidzin, glycitin, genistin 함량은 각각 248.72 , 141.76 , 및 $163.75 \mathrm{\mu g} / \mathrm{g}$ 이었으며 glycosides 총 함량은 554.23 $\mathrm{\mu g} / \mathrm{g}$ 이었다. 진양콩과 우람콩의 glycosides 총 함량은 각각 442.67 및 $836.46 \mathrm{\mu g} / \mathrm{g}$ 으로 우람콩에서 가장 많은 양이 검출 되었다. Malonyl glycosides 총 함량 역시 새단백(874.26 ㅆ $\mathrm{g} / \mathrm{g})$ 및 진양콩 $(1,979.95 \mathrm{\mu g} / \mathrm{g})$ 보다 우람콩 $(2,975.86 \mu \mathrm{g} / \mathrm{g})$ 에 서 가장 많은 함량이 검출되었다. 비배당체 형태의 daidzein, glycitein, 및 genistein 함량은 새단백콩에서는 각각 115.60 , 18.95 , 및 $110.59 \mu \mathrm{g} / \mathrm{g}$ 이었고 진양콩에서는 $37.78,21.21$. 및 $42.48 \mu \mathrm{g} / \mathrm{g}$ 이었고 우람콩에서는 $104.69,28.60$, 및 98.31 $\mu \mathrm{g} / \mathrm{g}$ 이 검출되었다. 이에 따라 비배당체 이소플라본 총 함 량은 진양콩 $(101.47 \mu \mathrm{g} / \mathrm{g})$ 이 가장 낮았고 새단백 $(245.14 \mu$ $\mathrm{g} / \mathrm{g})$ 과 우람콩 $(231.60 \mathrm{\mu g} / \mathrm{g})$ 은 유사한 함량을 나타내었다. 한편 이소플라본 총 함량은 우람콩이 $4,043.92 \mu \mathrm{g} / \mathrm{g}$ 으로 


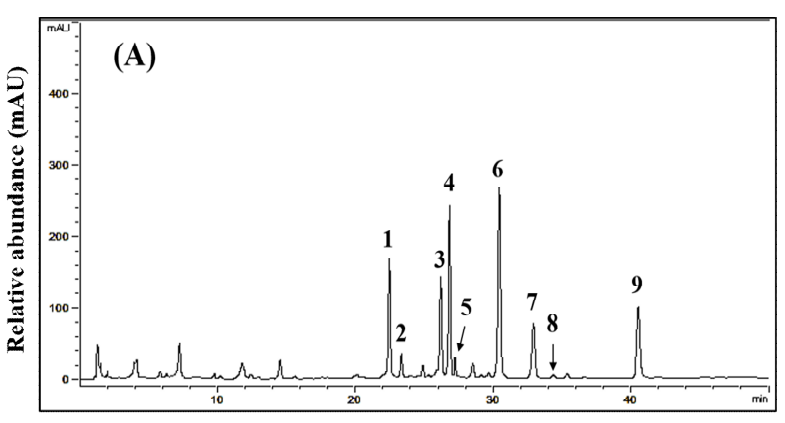

Retention time (min)

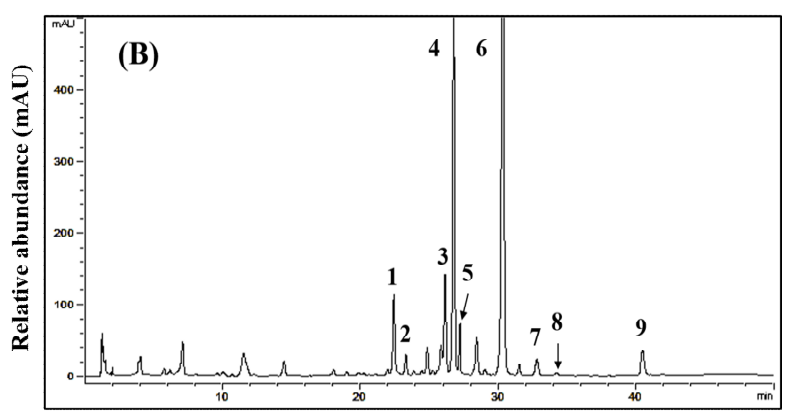

Retention time (min)

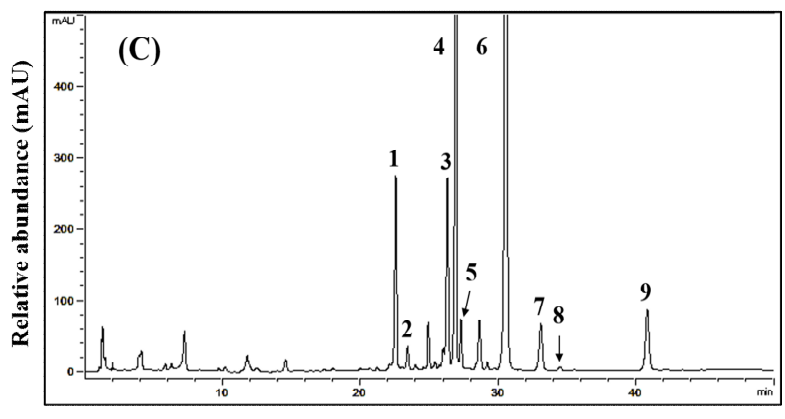

Retention time (min)

Fig. 1. Comparison of HPLC chromatogram of 9 isoflavones in specific soybean cultivars.

A, Saedanbaek soybean cultivar; B, Jinyang soybean cultivar, C, Wooram soybean cultivar. 1, daidzin; 2, glycitin; 3, genistin; 4, malonyl daidzin; 5, malonyl glycitin; 6, malonyl genistin; 7, daidzein; 8, glycitein; 9, genistein.

가장 많은 것으로 나타났다(Table 4).

일반적으로 이소플라본 각각의 유도체 함량과 조성은 1 차적으로 콩 품종에 의해 결정되고 2 차적으로는 콩의 발 아나 발효와 같은 가공 기술에 의해 결정된다(6). 본 연구 결과에서는 새단백콩과 우람콩의 daidzein, genistein, 및 glycitein 함량은 서로 유사하였으나 진양콩의 경우 이 두 품종과 비교하였을 시 극히 낮은 함량을 보였고 이는 같은 품종이라도 재배지역에 따라 함량 차이를 보인다는 Eldrige 와 $\operatorname{Kwolek}(27)$ 의 연구 결과와 유사한 것으로 추정된다. 또 한 이소플라본 중 glycitein의 경우 배축에 많은 양이 존재하 고(27) daidzein과 genistein은 자엽에 많은 양이 존재한다고 보고되었다(28). 본 연구 결과에서도 마찬가지로 세 품종간 glycitein 함량은 이 외 이소플라본 유도체에 비해 적은 양이 검출되어 $\mathrm{Kim}$ 등(28)의 연구 결과와 유사한 것으로 사료되
며 daidzein 및 genistein 함량 역시 glycosides 및 malonyl glycosides 함량에 비해 비교적 적은 양이 검출되었으므로 Akagi 등(29)의 연구 결과와 유사한 것으로 판단된다.

\section{특이 콩 품종별 항산화 및 효소 저해 활성 비교}

품종별 원료콩의 항산화 활성과 소화효소 저해 활성 측 정 결과는 Fig. 2와 Fig. 3에 나타낸 바와 같다. DPPH는 $54.99 \%$ 로 우람콩이 새단백(37.30\%) 및 진양콩(29.92\%)보 다 라디칼 소거능이 좀 더 높게 측정되었다(Fig. 2A). ABTS 는 $\mathrm{DPPH}$ 라디칼 소거능에 비해 전체적으로 약 2 배 가량 증가하는 현상을 보였다. 새단백콩의 ABTS 소거활성은 $89.78 \%$ 로 나타났으며 이는 $\mathrm{DPPH}$ 와 비교하였을 시 2.4배
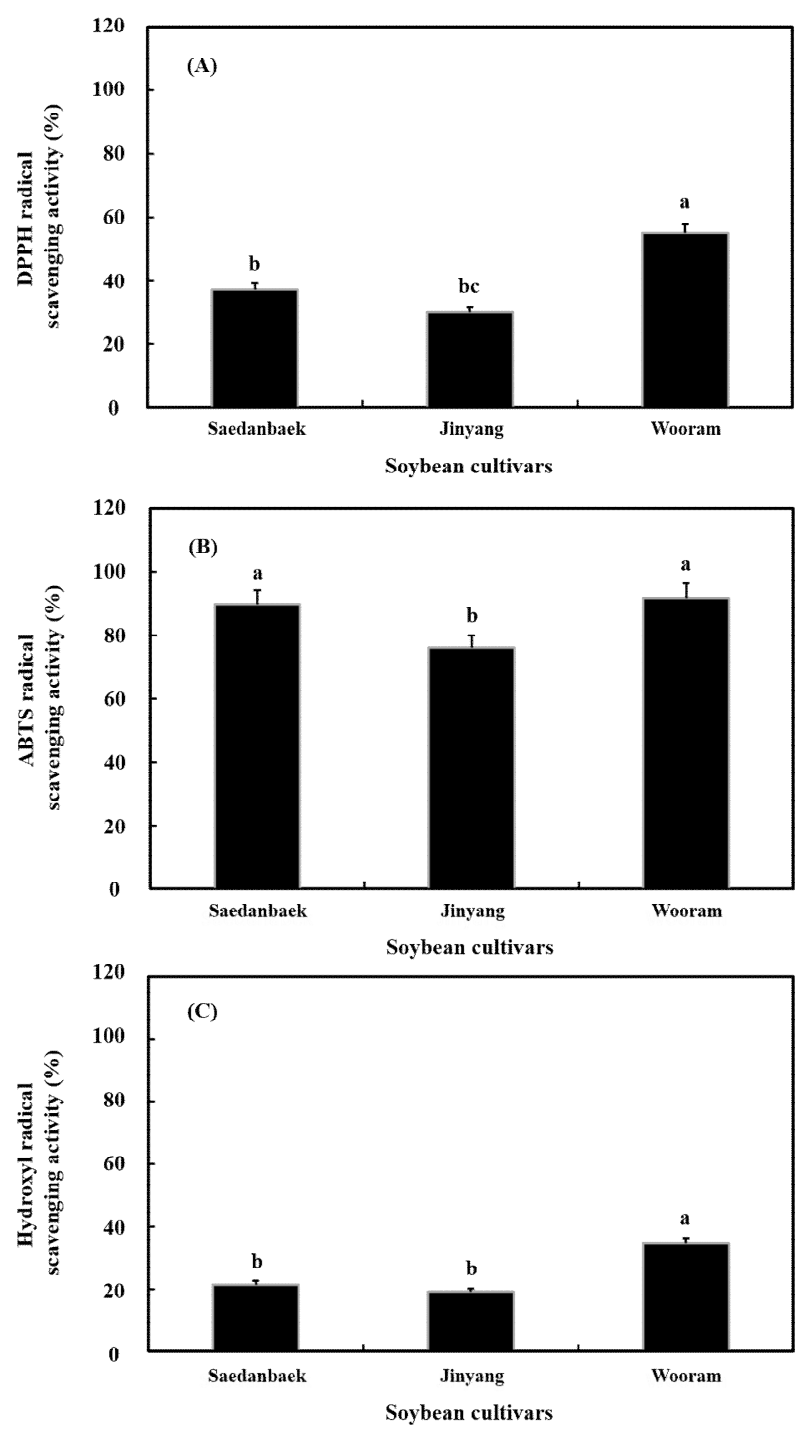

Fig. 2. Comparison of antioxidant activity in specific soybean cultivars.

(A); DPPH, (B); ABTS, and (C); hydroxyl radical scavenging activities. Means with different lowercase letters $(a-c)$ indicate significant $(p<0.05)$ differences of samples by Duncan's multiple range test. 
Table 4. Comparison of isoflavone contents in specific soybean cultivar

\begin{tabular}{|c|c|c|c|}
\hline \multirow{2}{*}{$\begin{array}{l}\text { Contents } \\
(\mu \mathrm{g} / \mathrm{g})\end{array}$} & \multicolumn{3}{|c|}{ Soybean cultivars } \\
\hline & Saedanbaek & Jinyang & Wooram \\
\hline \multicolumn{4}{|c|}{ Glycosides } \\
\hline Daidzin & $248.72 \pm 12.44^{\mathrm{fl} 1)}$ & $167.62 \pm 8.38^{\mathrm{f}}$ & $373.58 \pm 18.68^{\mathrm{e}}$ \\
\hline Glycitin & $141.76 \pm 7.09^{9}$ & $115.74 \pm 5.79^{\mathrm{f}}$ & $154.65 \pm 7.73^{\mathrm{f}}$ \\
\hline Genistin & $163.75 \pm 8.19^{\mathrm{g}}$ & $159.30 \pm 7.97^{\mathrm{f}}$ & $308.24 \pm 15.41^{\mathrm{e}}$ \\
\hline Total & $554.23 \pm 27.71^{\mathrm{c}}$ & $442.67 \pm 22.13^{\mathrm{e}}$ & $836.46 \pm 41.82^{d}$ \\
\hline \multicolumn{4}{|c|}{ Malonyl glycosides } \\
\hline Daidzin & $349.72 \pm 17.49^{f}$ & $752.08 \pm 37.60^{d}$ & $1,341.24 \pm 67.06^{\mathrm{C}}$ \\
\hline Glycitin & $57.79 \pm 2.89^{\mathrm{h}}$ & $119.78 \pm 5.99^{f}$ & $115.96 \pm 5.80^{f}$ \\
\hline Genistin & $466.76 \pm 23.34^{d}$ & $1,108.09 \pm 55.40^{c}$ & $1,518.67 \pm 75.93^{\mathrm{c}}$ \\
\hline Total & $874.26 \pm 43.71^{\mathrm{b}}$ & $1,979.95 \pm 99.00^{b}$ & $2,975.86 \pm 148.79^{b}$ \\
\hline \multicolumn{4}{|c|}{ Aglyones } \\
\hline Daidzein & $115.60 \pm 5.78^{g}$ & $37.78 \pm 1.89^{\mathrm{g}}$ & $104.69 \pm 5.23^{\mathrm{f}}$ \\
\hline Glycitein & $18.95 \pm 0.95^{\mathrm{h}}$ & $21.21 \pm 1.06^{g}$ & $28.60 \pm 1.43^{g}$ \\
\hline Genistein & $110.59 \pm 5.53^{g}$ & $42.48 \pm 2.12^{\mathrm{g}}$ & $98.31 \pm 4.92^{\mathrm{g}}$ \\
\hline Total & $245.14 \pm 12.26^{\mathrm{e}}$ & $101.47 \pm 5.07^{\mathrm{f}}$ & $231.60 \pm 11.58^{\mathrm{e}}$ \\
\hline Total isoflavones & $1,673.63 \pm 83.68^{\mathrm{a}}$ & $2,524.09 \pm 126.20^{a}$ & $4,043.92 \pm 202.20^{\mathrm{a}}$ \\
\hline
\end{tabular}

${ }^{1}$ All values are presented as the mean \pm SD of triplicate determination. Means with different lowercase letters $(a-h)$ indicate significant $(\mathrm{p}<0.05)$ differences of samples by Duncan's multiple range test.
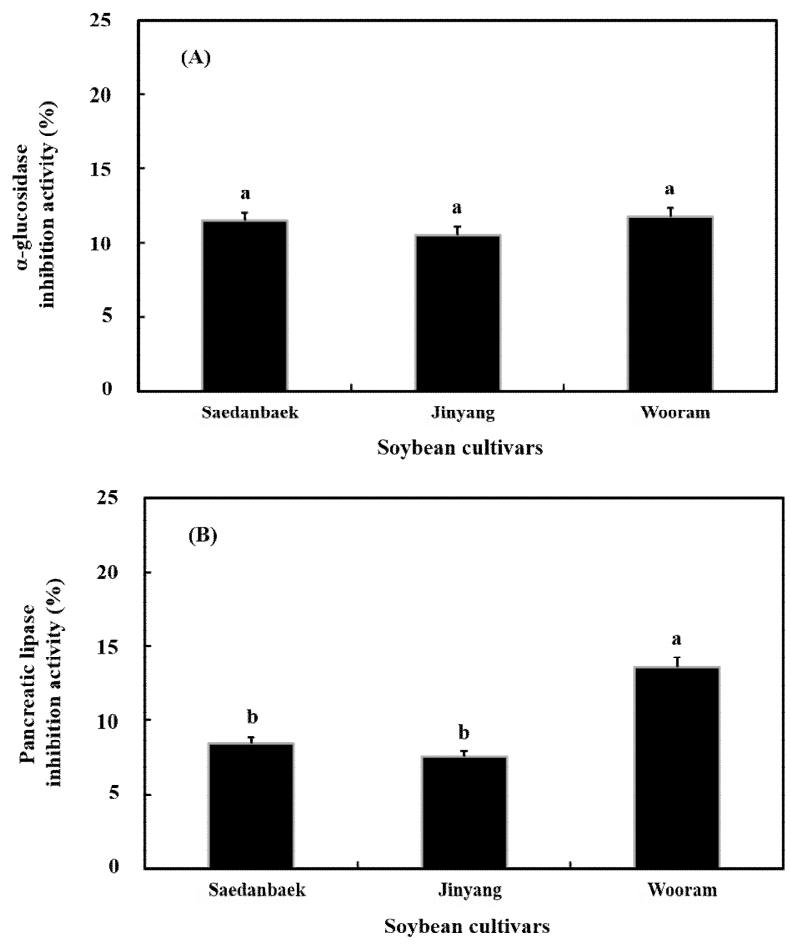

Fig. 3. Comparison of enzyme inhibition activity in specific soybean cultivars.

(A); a-glucosidase and (B); pancreatic lipase inhibition activities.

Means with different lowercase letters $(a-b)$ indicate significant $(p<0.05)$ differences of samples by Duncan's multiple range test.
증가하였고 진양콩은 $76.23 \%$ 로 2.5 배 상승한 것으로 나타 났다. 우람콩은 $91.84 \%$ 로 이들 중 가장 높은 ABTS 라디칼 소거활성을 나타내었고 $\mathrm{DPPH}$ 에 비해 약 1.6 배 상승하였다 (Fig. 2B). Hydroxyl은 새단백콩이 $21.45 \%$ 로 측정되어졌고 우람콩은 $34.61 \%$ 로 가장 우수하였고 진양콩은 $19.10 \%$ 로 가장 낮은 소거활성을 보였으며 DPPH에 비해 약 1.5 배 가량 감소한 것으로 나타났다(Fig. 2C).

한편 a-glucosidase 저해활성 결과, 새단백콩은 $11.47 \%$ 를 나타내었고 진양콩은 $10.54 \%$, 우람콩은 $11.78 \%$ 로 비교적 낮은 탄수화물 분해효소 저해를 나타내었다(Fig. 3A). Pancreatic lipase 저해활성 역시 a-glucosidase 경향과 일치 하였으며 우람콩이 $13.56 \%$ 로 가장 높았고 새단백콩은 $8.45 \%$, 진양콩은 $7.56 \%$ 를 나타내었다(Fig. 3B).

$\mathrm{ABTS}$ 라디칼 소거능이 DPPH 및 hydroxyl보다 더 높게 측정되어지는 것은 보통 라디칼의 종류에 따른 차이가 있으 나 특히 수용성과 지용성 생리활성 물질 모두 측정되는 특성에 따른 차이가 가장 큰 것으로 사료된다(30). 한편 이러한 항산화 활성은 페놀릭스와 이소플라본과 같은 플라 보노이드 함량과 관계가 있다고 $\mathrm{Kim}$ 등(31)은 보고하여 항산화 활성은 이소플라본과 정의 상관관계가 있을 것으로 사료된다. 또한, a-glucosidase 활성을 저지할 경우 탄수화물 의 분해를 지연시키거나 일부는 분해되지 않아 결과적으로 당류 흡수율이 떨어지게 되므로 식후 혈당 감소 효과가 있다(32). 이러한 저해활성 향상에 도움을 주는 물질은 플라 
보노이드의 하나인 quercetin 성분으로 특히 a-glucosidase 를 비가역적으로 느리게 결합하여 비경쟁적 저해를 일으키 므로 당뇨 치료제로 잠재적 가치가 있을 것으로 Cho 등(33) 은 보고하였다. 보통 폴리페놀과 플라보노이드를 함유하고 있는 콩은 그 자체보다는 발효됨에 따라 항산화 활성과 효소 저해 활성이 우수한 것으로 보고되었다(34). 또한, 본 연구에서 측정한 pancreatic lipase는 효소의 작용이 지속적 으로 작용 시 중성지방이 분해되어 흡수되므로 결과적으로 는 체중 증가와 함께 만성 성인병에 노출되기가 쉽다(32). 그러므로 지방의 분해가 이루어지지 않도록 효소의 작용을 억제시켜 인체에 흡수되지 않고 배설된다면 성인병에 대한 위험도가 크게 감소될 것으로 사료된다. Lipase를 억제하는 데 관여하는 것은 보통 항산화 효과를 증대시키는 물질로 보고되어 있으며 콩에 함유된 이소플라본이 가장 대표적이 다(34). 특히, 이들 이소플라본들은 daidzin $\rightarrow$ daidzein, genistin $\rightarrow$ genistein, glycitin $\rightarrow$ glycitein으로 발효 시 화합 물의 변화가 일어남과 동시에 효소 저해 활성이 증가하는 것으로 보고되어있다(6). 그러나 본 연구에서는 세 품종 모두 다소 낮은 활성을 보였고 이러한 결과는 콩의 발효 전(원료)과 발효 후(가공)의 차이가 가장 큰 요인일 것으로 판단된다.

따라서 지금까지의 연구결과로 볼 때 단백질, 지방산 및 아미노산 함량이 가장 많은 새단백 품종은 이미 알려진 대로 두부 가공적성에 탁월한 것으로 판단되며 진양 품종은 항산화 활성이 다소 낮게 측정되었으나 비린내가 결여된 품종이므로 콩국수 제조에 적합할 것으로 생각된다. 한편, 우람 품종은 이소플라본 함량이 가장 많고 이에 상응하여 항산화 활성이 가장 우수하므로 기능성 두유, 간장, 된장 등과 같은 콩 가공 및 발효 공정에 최적 품종이 될 것으로 기대된다.

\section{요 약}

본 연구에서는 특이 품종인 새단백, 진양, 및 우람콩으로 부터 1 차 대사체와 2 차 대사체 조성 및 항산화 활성을 비교 분석하였다. 세 품종간 영양성분 분석 결과, 수분(7.9-9.8 $\mathrm{mg} / \mathrm{g})$, 회분(4.8-4.9 mg/g), 조지방 $(14.2-16.5 \mathrm{mg} / \mathrm{g})$, 및 탄수 화물 $(21.4-35.0 \mathrm{mg} / \mathrm{g})$ 을 함유하고 있었고 특히 새단백콩은 조단백 함량 $(47.5 \mathrm{mg} / \mathrm{g})$ 이 가장 많았다. 지방산 분석 결과로 는 진양콩에서 포화 지방산인 palmitic acid, arachidic acid, behenic acid, lignoceric acid 함량이 각각 1,392.1, 490.8, $37.5,44.9,16.6 \mathrm{mg} / 100 \mathrm{~g}$ 으로 가장 많았다. 불포화 지방산 중에서는 linoleic acid(새단백), oleic acid(진양), a-linolenic $\operatorname{acid}($ 우람)가 각각 $8,258.0,2,896.8,906.5 \mathrm{mg} / 100 \mathrm{~g}$ 으로 높 게 검출되었다. 아미노산 총 함량은 새단백콩에서 $44,598.54 \mathrm{mg} / 100 \mathrm{~g}$ 으로 가장 높았으며 진양 $(21,525.93$ $\mathrm{mg} / 100 \mathrm{~g})$ 과 우람콩 $(26,250.63 \mathrm{mg} / 100 \mathrm{~g})$ 과 비교하였을 시 2 배 또는 1.6배 높았다. 부가적으로, glycosides, malonyl glycosides, aglycones 함량은 각각 $836.46,2,975.86$, 및 $231.60 \mu \mathrm{g} / \mathrm{g}$ 으로 우람콩에서 가장 많은 것으로 나타났다.

\section{감사의 글}

이 논문은 2018년도 경남과학기술대학교 박사 후 연수과 정 지원사업의 지원을 받아 연구되었습니다.

\section{References}

1. Lee S, Lee YB, Kim HS (2013) Analysis of the general and functional components of various soybeans. J Korean Soc Food Nutr, 42, 1255-1262

2. Coward L, Barnes NC, Setchell KDR, Barness B (1993) Genistein, daidzein, and their $\beta$-glucoside conjugates: antitumor isoflavones in soybean foods from american and asin diets. J Agric Food Chem, 41, 1961-1967

3. Lee JH, Hwang CE, Son KS, Cho KM (2019) Comparison of nutritional constituents in soybeans during solid state fermentation times and screening for their glucosidase enzymes and antioxidant properties. Food Chem, 272, 362-371

4. Lee ES, Yi YS, Yoon ST, Lee HG (2009) Variation in antioxidant components of black soybean as affected by variety and cultivation region. Korean J Crop Sci, 54, 80-87

5. Kudou S, Fleury Y, Welt D, Magnolato D, Uchida T, Kitamura K, Okubo K (1991) Malonyl isoflavones glycosides in soybean seeds (Glycine max Merrill). Agric Biol Chem, 55, 2227-2233

6. Hwang CE, Cho KM, Kim SC, Joo OS (2018) Change in physicochemical properties, phytoestrogen content, and antioxidant activity during lactic acid fermentation of soy powder milk obtained from colored small soybean. Korean J Food Preserv, 25, 696-705

7. Yang M, Kwak JS, Jang SR, Jia YN, Park IS (2013) Antioxidant activity of soybean yogurt added to tomato extract by Bacillus subtilis and Lactobacillus plantarum Korean J Food Nutr, 26, 280-286

8. Cho KM, Ha TJ, Lee YB, Seo WD, Kim JY, Ryu HW, Jeong SH, Kang YM, Lee JH (2013) Soluble phenolics antioxidant properties of soybean (Glycine $\max \mathrm{L}$.) cultivars with varying seed coat colours. J Funct Foods, 
5, 1065-1076

9. Kim MY, Jang GY, Ji YM, Kim KM, Kim HS, Lee JS, Jeong HS (2016) Isoflavone composition and estrogenic activity of germinated soybeans (Glycine max) according to variety. J Korean Soc Food Sci Nutr, 45, $1430-1437$

10. Kim SL, Lee YH, Chi HY, Lee SJ, Kim SJ (2007) Diversity in lipid contents and fatty aid composition of soybean seeds cultivated in korea. Korean J Crop Sci, 52, 348-357

11. Im JY, Kim SC, Kim SN, Choi YM, Yang MR, Cho IH, Kim HR (2016) Protein and amino-acid contents in backtae, seoritae, huktae, and seomoktae soybean with different cooking methods. Korean J Food Cook Sci, 32, 567-574

12. Hwang CE, Haque MA, Lee JH, Song YH, Lee HY, Kim SC, Cho KM (2018) Bioconversion of $\gamma$ -aminobutyric acid and isoflavone contents during the fermentation of high-protein soy powder yogurt Lactobacillus brevis. Appl Biol Chem, 61, 409-421

13. Kim IS, Lee SJ, Lee HJ, Oh SJ, Chung JI, Sung NJ (2014) Quality characteristics and antioxidant activity of tofu made from lipoxygenase-free genotypes. Korean J Food Preserv, 21, 215-223

14. Ko JM, Han WY, Kim HT, Lee YH, Choi MS, Lee BW, Shin SU, Seo JH, Oh KW, Yun HT, Jeon MG, Choi KH, Shin JH, Lee EJ, Yang S, Oh IS (2016) Soybean cultivar for soy-paste, 'Uram'with mechanization harvesting, large seed, disease resistance and high yield. Korean J Breed Sci, 48, 301-306

15. http://www.foodsafetykorea.go.kr/foodcode/index.jsp

16. Lee JH, Hwang CE, Cho EJ, Song YH, Kim SC, Cho KM (2018) Improvement of nutritional components and in vitro antioxidative properties of soy-powder yogurts using Lactobacillus plantarum. J Food Drug Analy, 26, 1054-1065

17. Hwang JH, Oh YS, Lim JH, Park JE, Kim MB, Yoon HS, Lim SB (2009) Physiological properties of Jeju traditional Doenjang. J Korean Soc Food Sci Nutr, 38, 1656-1663

18. Joo OS, Hwang CE, Hong SY, Sin EC, Nam SH, Cho KM (2018) Antioxidative and digestion enzyme inhibitory activity of Ganoderma lucidum depends on the extraction solvent. Korean J Food Preserv, 25, 124-135

19. Lee JH, Hwang CE, Son KS, Cho KM (2019) Comparison of nutritional constituents in soybeans during solid state fermentation times and screening for their glucosidase enzymes and antioxidant properties. Food Chem, 272, 362-371

20. Cho KM, Hwang CE, Joo OS (2017) Change of physicochemical properties, phytochemical contents and biological activities during the vinegar fermentation of Elaeagnus multiflora fruit. J Food Preserv, 24, 125-133

21. Kang SH (2012) Physicochemical and functional characteristics of traditional Meju and Doenjang with soybean in different seeding times. MS Thesis, Seoul National University, Seoul Korea, p 12-371

22. Jung GH, Kim SK, Lee JE, Woo KS (2018) Physicochemical characteristics of sorghum according to variety and seeding period. J Korean Soc Food Sci Nutr, 47, 422-428

23. Lee JH, Kim HJ, Lee BW, Lee YY, Jeon YH, Lee BK, Woo KS (2018) Quality and physicochemical characteristics of soybean with variety and different seeding periods. J Korean Soc Food Sci Nutr, 47, 804-812

24. Ohtake N, Kawachi T, Sato A, Okuyama I, Fujikake H, Sueyosh K, Sueyoshi T (2001) Temporary application of nitrate to nitrogen-deficient soybean plants at the mid to late-stages of seed development increased the accumulation of the $\beta$-subunit of $\beta$-conglycinin, a major seed storage protein. Soil Sci Plant Nutr, 47, 195-203

25. Kim MJ, Kim KS (2005) Functional and chemical composition of Hwanggumkong, Yakong and Huktae. Korean J Food Cook Sci, 21, 844-849

26. Kim KS, Kim MJ, Lee KA, Kwon DY (2003) Physico-chemical properties of Korean traditional soybeans. Korean J Food Sci Technol, 35, 335-341

27. Kim YH (2002) Current achivement and perspective of seed quality evaluation in soybean. Korean J Crop Sci, 47, 95-106

28. Eldridge AC Kwolek WF (1983) Soybean isoflavone: effect of environment and variety on composition. J Agric Food Chem, 31, 394-396

29. Kim SR, Hong HD, Kim SS (1999) Some properties and contents of isoflavone in soybean and soybean foods. Korea Soybean Digest, 16, 35-46

30. Akagi I, Nishihara M, Ueda S, Yokoyhama A, Asano Y, Saeki Y (2007) Isoflavone content of soybean cultivars for warm districts grown in Miyazaki prefecture. Jpn J Crop Sci, 76, 454-458

31. Choi JS, Kim HY, Seo WT, Lee JH, Cho KM (2012) Roasting enhances antioxidant effect of bitter melon (Momordica charantia L.) increasing in flavan-3-ol and 
phenolic acid contents. Food Sci Biotechnol, 21, 19-26

32. Kim JH, Hwang CE, Lee CK, Lee JH, Kim GM, Jeong SH, Shin JH, Kim JS, Cho KM (2014) Characteristics and antioxidant effect of garlic in the fermentation of Cheonggukjang by Bacillus amyloliquefaciens MJ1-4. J Microbiol Biotechnol, 24, 959-968

33. Cho KM, Hwang CE, Joo OS (2017) Change of physicochemical properties, phytochemical contents and biological activities during the vinegar fermentation of Elaeagnus multiflora fruit. Korean J Food Preserv, 24, 125-133
34. Lee DS, Kim JG, and Lee SH (2006) Inhibition of a -glucosidase activity by quercetin. Kor J Microbiol Biotechnol, 34, 368-372

35. Hwang CE, Lee DH, Joo OS, Lee HY, Kim SC, Park KS, Um BS, Cho KM (2017) Comparison of physiochemical property, phytochemical contents, and biological activity of soy sauce added with bitter melon powder. Korean J Food Preserv, 24, 1138-1148 